\title{
ASSESSMENT TOOLS DISSEMINATION OF METHODOLOGICAL SUPPORT FOR THE TEACHER OF TECHNICAL SUBJECTS IN SLOVAK AND CZECH REPUBLIC
}

\author{
Gabriel BÁNESZ; Danka LUKÁC̆OVÁ
}

\begin{abstract}
Following an academic initiative to assure quality in teaching technology and to technology related other subjects, it was decided at the Department of Technology and Information Technologies at the Faculty of Education of Constantine the Philosopher in Nitra to provide in-service teachers teaching these school subjects, whether as qualified or unqualified, a methodological help and support aimed at development of the technology education at primary and secondary schools (the second level of primary schools and eight-year grammar schools). A tool of this support and assisting to teaching the school subject technology has become the above-described web locality EduTech Portal (http://etp2.pf.ukf.sk/). On the basis of the cooperation between the Department of Technology and Information Technologies at the Faculty of Education, Constantine the Philosopher University in Nitra, and the Department of Technical Education and Information Technology at the Faculty of Education, Palacký University in Olomouc, the locality has been reconstructed and adapted also for the needs of the teachers in the Czech Republic
\end{abstract}

Key words: teaching technology; quality of education; methodological support; teaching materials; internet portal; web locality EduTech Portal; verification of the effectiveness.

\section{ZHODNOTENIE DISSEMINÁCIE NÁSTROJOV METODICKEJ PODPORY PRE UČITELOV TECHNICKÝCH PREDMETOV V SLOVENSKEJ a ČESKEJ REPUBLIKE}

Resumé: V rámci akademickej iniciatívy sledujúcej zabezpečovanie kvality vyučovania predmetu technika ako aj d'alších $\mathrm{s}$ technickou výchovou súvisiacich predmetov Katedra techniky a informačných technológií Pedagogickej fakulty Univerzity Konštantína Filozofa v Nitre sa rozhodla poskytovat metodickú pomoc a podporu kvalifikovaným aj nekvalifikovaným učitel'om zabezpečujúcim výučbu uvedených predmetov na základných školách a osemročných gymnáziách. Prostriedkom poskytovania tejto pomoci sa stala novo vytvorená opísaná webová lokalita EduTech Portal (http://etp2.pf.ukf.sk/). Na základe spolupráce medzi Katedrou techniky a informačných technológií Pedagogickej fakulty Konštantína Filozofa v Nitre a Katedrou technickej a informačnej výchovy Pedagogickej fakulty Univerzity Palackého v Olomouci novo zriadená lokalita bola reštrukturalizovaná a adaptovaná aj pre potreby učitel'ov v Českej republike.

Kl'účové slová: technické vzdelávanie, kvalita vzdelávania metodická pomoc, metodické materiály a učebné pomôcky, webová lokalita EduTech Portal, vyhodnotenie výsledkov.

\section{1 Úvod}

Projekt Disseminácia nástrojov metodickej podpory pre učitel'ov technických predmetov bol zameraný na adaptovanie webovej lokality EduTech Portal na ciel'ovú skupinu učitelov predmetov technického zamerania v Českej a aj Slovenskej republike. Uvedená lokalita bola počas riešenia projektu uvedená do ostrej prevádzky v oboch štátoch v januári 2013 za účelom poskytovania metodickej podpory učitel'om technického zamerania pôsobiacich na základných, stredných školách a osemročných gymnáziách. Projekt riešil analogické možnosti získavania metodickej podpory pre učitel'ov v praxi, vychádzajúc z identifikácie ich potrieb.

Projekt riešil medzinárodný výskumný tým, zastúpený rovnomerne $\mathrm{z}$ oboch partnerských strán v nasledovnom zložení:

- $\quad \mathrm{Za}$ slovenskú stranu: doc. PaedDr. Gabriel Bánesz, PhD., doc. PaedDr. Danka Lukáčová, PhD., prof. PaedDr. Alena Hašková, PhD., Mgr. Juraj Sitáš, PhD.

- $\quad \mathrm{Za}$ českú stranu: doc. Ing. Čestmír Serafín, Dr. Ing-Paed. Mgr. Martin Havelka, PhD., PaedDr. Jiř́ Dostál, PhD., Mgr. Jan Kubrický, PhD. 
Výskum a teda celý projekt prebiehal v nasledovných etapách, ktoré zodpovedali stanoveným ciel'om pre celú dobrú riešenia:

1. Technické zabezpečenie prevádzky webovej lokality v $\breve{C} R$.

2. Overenie organizačnej štruktúry systému komunikácie $\mathrm{v}$ digitálnom informačnom systéme v Českej republike.

3. Komparácia ciel'ov, obsahu a používaných metód pre predmety technika/technická výchova.

4. Sprístupnenie webovej lokality pre používatel'ov na školách $\mathrm{v}$ Českej republike.

5. Zber výskumných údajov prostredníctvom portálu. (Projekt APVV, 2011)

Všetky stanovené ciele projektu boli splnené, pričom $v$ záverečnej fáze riešenia projektu riešitelia použili pre zistenie spätnej väzby od registrovaných používatel'ov webovej lokality dotazník. Prostredníctvom tohto dotazníka zist’ovali, ako vnímajú registrovaní používatelia nový prostriedok pre ich prípravu na vyučovanie.

\section{Výskumné metódy použité na zist'ovanie} stavu využívania EduTech Portalu

Ako hlavný výskumný nástroj bol použitý dotazník. Pri jeho zostavovaní sa vychádzalo zo skúseností slovenských riešitel'ov spoločného projektu. Dotazník obsahoval 11 položiek, ktoré boli zamerané na nasledovné skutočnosti. Prvou položkou sme zist'ovali, aké materiály respondenti preferujú pri príprave na výučbu predmetu s technickým zameraním. Položka ponúkala tri informačné zdroje, pričom vo štvrtej možnosti „iné“ mohli vyjadrit' vlastné zdroje, ktoré používajú pri svojej príprave.

Druhá položka sa zameriavala na konkrétne edukačné webové lokality, ktoré môžu respondenti poznat' a použivat' $\mathrm{v}$ predmete technika. Svoje odpovede mohli vyjadrit' v dvoch možnostiach. Prvá nepoznám žiadne a v druhej „iné“ mohli dopísat' konkrétne názvy takýchto lokalít.

Tretia položka sa už konkrétne venovala spoločnej webovej lokalite EduTech Portal z pohl'adu jej prehl'adnosti a možnosti navigácie. Z pätčlennej navrhnutej škály mohli vybrat' od označenia 1 (prehl'adná) až po možnost' 5 (neprehl'adná).

Nasledujúca položka bola zameraná na zistenie názorov, či webová lokalita EduTech Portal môže pomôct' učitel'ovi v príprave na vyučovanie. Odpovede boli zoradené v škále od „Áno vel'mi“ až po „Nie“ či „Neviem sa vyjadrit"“.

Webová lokalita ponúka vo svojom obsahu rôzne metodické materiály a elektronické učebné pomôcky pre používatel'ov. $\mathrm{Z}$ tohto dôvodu mali respondenti vybrat' $\mathrm{z}$ ponúkaného zoznamu tie, ktoré by využili vo vyučovaní.

Štruktúra webovej lokality je vyhotovená a dostupná $\mathrm{v}$ dvoch jazykových mutáciách a obsahoch. Šiesta položka dotazníka preto zistovala, či sa respondenti oboznámili s obsahmi určenými pre používatel'ov v Slovenskej republike. V prípade, že respondent na túto položku odpovedal „áno“, tak následne siedma položka zist'ovala, či mali problémy so slovenským jazykom.

Webová lokalita je prístupná v oboch krajinách od januára 2013. Preto ôsma položka bola zameraná na spôsob, resp. informačný zdroj, z ktorého sa respondenti dozvedeli o jej existencii.

Deviata položka zist’ovala problémy súvisiace s prihlásením sa na webovú lokalitu.

Desiata otázka zist'ovala, či bola webová lokalita EduTech Portal inšpiráciou pre vyhl'adávanie podobných lokalít určených pre podporu práce učitel'a.

$\mathrm{V}$ jedenástej položke mohli respondenti vyjadrit' svoj názor, aké zmeny by privítali na uvedenej webovej lokalite.

Dotazník bol odoslaný 86 respondentom, pričom úplne vyplnených sa vrátilo 84 . $Z$ tohto celkového počtu bolo 29 žien a 55 mužov. Išlo hlavne o študentov učitel'stva technickej výchovy - 76 respondentov a 19 učitel'ov z praxe.

Získané výsledky z dotazníka boli spracované vo forme tabuliek a grafov, pričom na ich kvantitatívne vyhodnotenie bola použitá popisná štatistika.

\section{Výsledky z dotazníkového prieskumu}

Prvou položkou bolo zist'ované, aké materiály preferujú respondenti pri príprave na výučbu predmetu technika (praktické činnosti). Respondenti mohli vybrat' z viacerých ponúkaných možností (graf 1).

Najviac respondentov preferuje pre svoju prípravu na vyučovanie prostredie internetu, 78 opýtaných, 43, využíva knihy a učebnice, 14 časopisy. Piati uviedli aj iné možnosti. Išlo hlavne o vysokoškolské skriptá a konzultácie s odborníkom. 


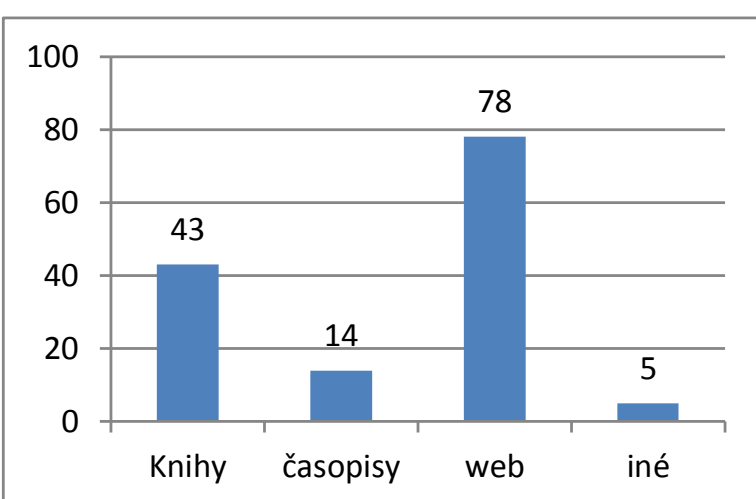

Graf 1 Informačné zdroje pre prípravu na vyučovanie

Z uvedeného vyplýva, že ,internet“ je v súčasnosti najväčším zdrojom informácií pre učitel'ov, ktorí ho využívajú na prípravu na vyučovanie.

Druhá položka bola zameraná na edukačné webové lokality využitel'né $\mathrm{v}$ predmete technika. Respondenti mali uviest', či takéto poznajú a využívajú.

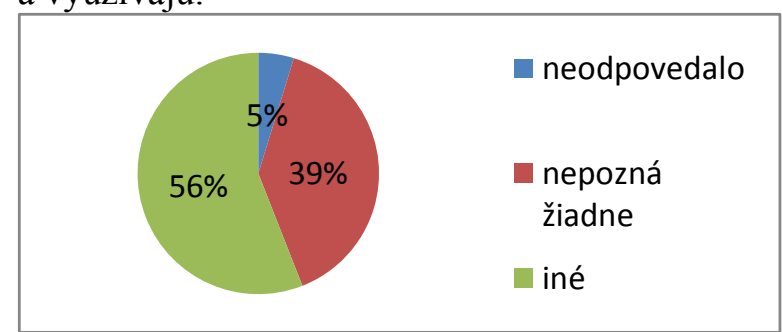

Graf 2 Preferované edukačné webové lokality

Pät' percent respondentov na túto položku neodpovedalo, takmer $40 \%$ nepozná žiadne a $56 \%$ zvolilo možnost' iné, pričom najčastejšie uvádzali nasledovné: wikipédia, Google, stránky veskole.cz a pod. Z uvedených odpovedí v možnosti iné, je zaujímavá tá skutočnost', že za „Edukačné webové lokality“ respondenti považujú aj internetové prehliadače a samotnú Wikipédiu. V prípade posledne menovanej a nesporne zaujímavej lokalite, je ale spochybnitel'ná objektivita poskytovaných informácií. Jej obsah je síce možno použit' na prípravu, no len v prípade dôkladnej osobnej a kritickej analýze jej obsahu. V každom prípade ale ju nemôžeme považovat' za výsostne lokalitu určenú na edukačné účely.

Tret'ou položkou výskumníci zist'ovali, ako vnímajú registrovaní používatelia prehl'adnost' navrhnutej webovej lokality. Svoj názor mohli vyjadrit' pomocou pät' stupňovej škály od prehl'adnej označenej číslom 1 po neprehl'adnú označenej číslom 5.

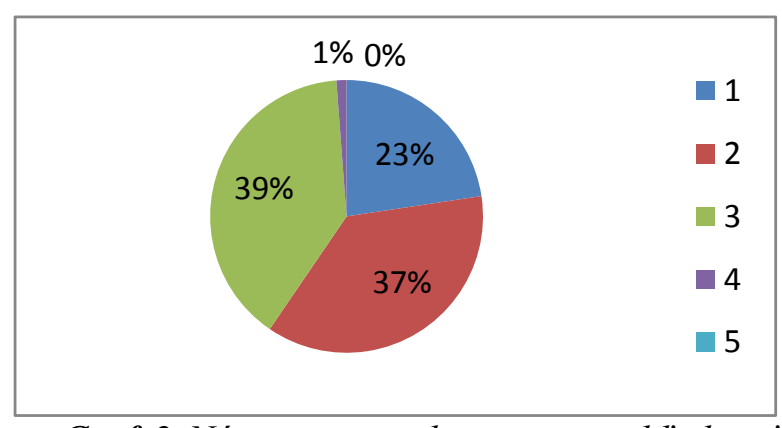

Graf 3 Názory respondentov na prehl'adnost' lokality

$23 \%$ respondentov webovú lokalitu zhodnotilo ako prehl'adnú s hodnotením 1, $37 \%$ s hodnotením 2 a $39 \%$ s hodnotením 3. Môžeme konštatovat', že prehl'adnost' stránky bola hodnotená skôr pozitívne. Nik z respondentov nehodnotil v škále 4 a 5 .

Nasledujúca položka sa zameriavala na zistenie priameho využitia webovej lokality vo vyučovacom procese. Respondenti mali vyjadrit' svoj postoj odpoved'ou na otázku: „Myslíte si, že by Vám obsah webovej lokality EduTech Portal mohol pomôct' $\mathrm{v}$ príprave na vyučovanie?"

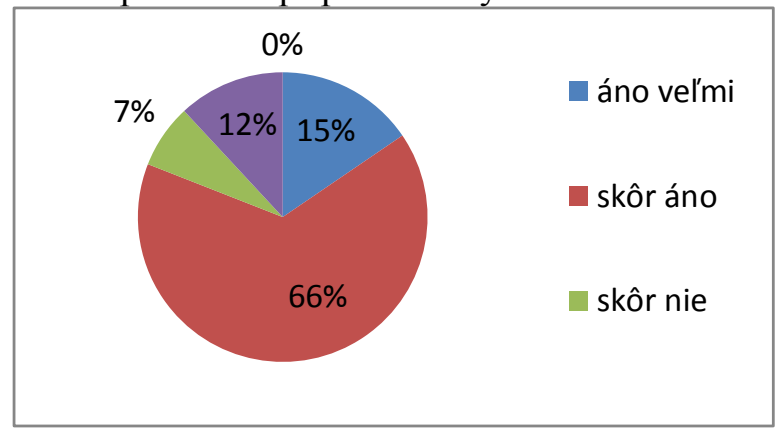

Graf 4 Hodnotenie EduTech Portalu zhl'adiska jeho využitia pri príprave na vyučovanie

Ako je z uvedeného zrejmé, tak respondenti by dokázali využit' obsah webovej lokality pri svojej príprave na vyučovanie $(81 \%$ odpovedí áno vel'mi a skôr áno). Obsah a zameranie lokality by nevyužilo $19 \%$. Položka ešte obsahovala možnost' „neviem sa vyjadrit'“, ktorú nezvolil nikto.

Webová lokalita obsahuje rôzne metodické materiály a učebné pomôcky pre využitie $\mathrm{v}$ technicky orientovaných predmetoch. V piatej položke mali respondenti uviest', ktoré z nich by vedeli využit' vo svojej praxi. Respondenti mohli vybrat' viacero $\mathrm{z}$ ponúkaných materiálov. 


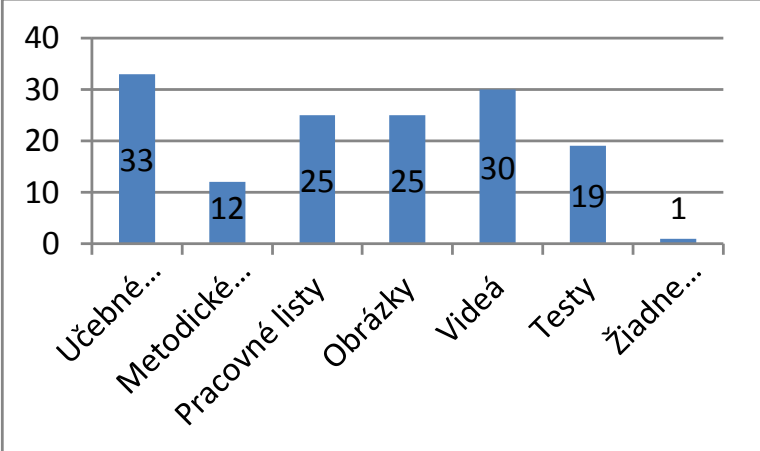

Graf 5 Využite jednotlivých materiálov z lokality

Ako je z uvedeného grafu zrejmé, tak najviac žiadané sú učebné pomôcky $\mathrm{v}$ elektronickej forme. Ide hlavne o prezentácie $\mathrm{k}$ jednotlivým tematickým celkom. Rovnako 33 respondentov prejavilo záujem o zverejnené videá. 25 respondentov malo záujem o pracovné listy a obrázky z lokality. Devätnásti by vedeli využit' testy na preverovanie vedomostí $\mathrm{v}$ jednotlivých tematických celkoch. Dvanást' respondentov malo záujem o metodické poznámky. Jeden respondent nemal záujem o žiadne z uvedených materiálov.

Šiesta a siedma položka boli zamerané na možné jazykové bariéry $\mathrm{v}$ slovenskej a českej mutácii webovej lokality. V šiestej položke bolo zist'ované, či si respondenti prezreli aj slovenskú čast' webovej lokality. Pokial' odpovedali v šiestej položke áno, tak $\mathrm{v}$ siedmej sa mali vyjadrit', či mali problémy porozumiet' obsahu webovej lokality v slovenskom jazyku.

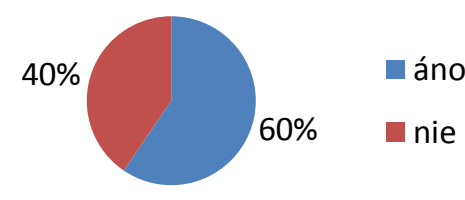

Graf 6 Odpovede respondentov na šiestu položku

Z grafu vyplýva, že $60 \%$ respondentov nemalo problém s obsahom v Slovenskom jazyku. Títo respondenti následne odpovedali aj na položku 7 nasledovne.

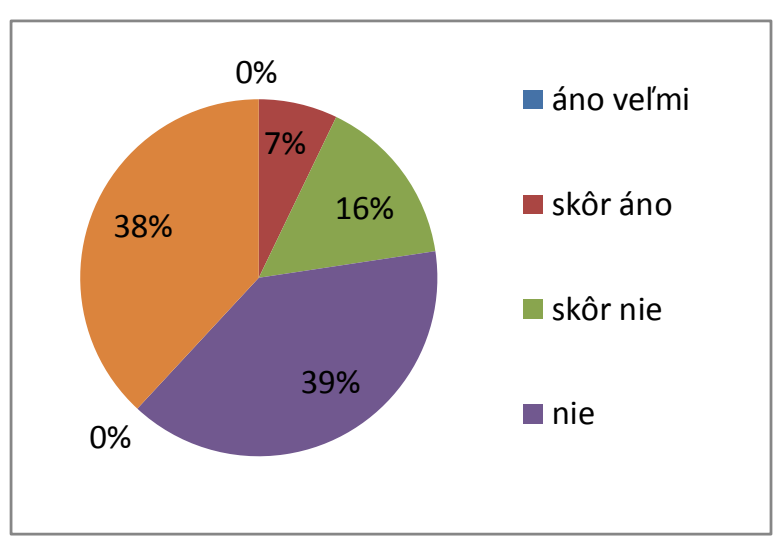

Graf 7 Odpovede respondentov na siedmu položku

Nik s respondentov sa nevyjadril $\mathrm{v}$ tom zmysle, že vôbec nerozumel obsahu a len $16 \%$ opýtaných uviedlo, že isté problémy s pochopením obsahu slovenskej verzie malo. $77 \%$ opýtaných nemalo problémy s jazykom.

Ôsma položka zist'ovala spôsob, ako sa respondenti dozvedeli o existencii webovej lokality.

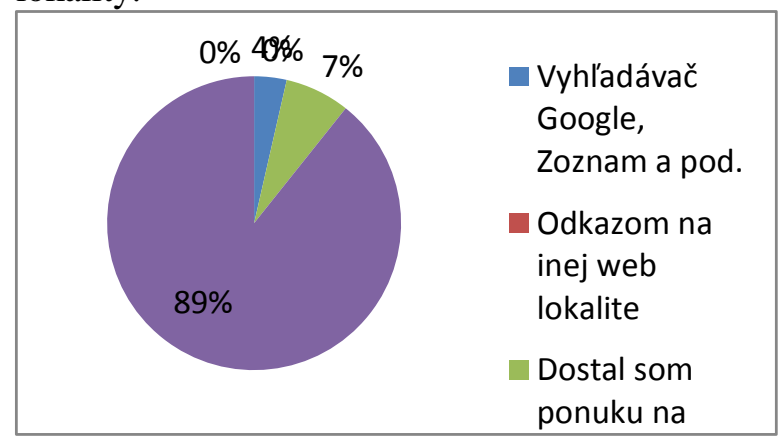

Graf 8 Odpovede respondentov na ôsmu položku dotaznika

Takmer $89 \%$ respondentov dostalo tip na webovú lokalitu od učitel'a, priatel'a a známeho a len $11 \%$ získalo informáciu o existencii EduTech Portalu cez internet.

Nikto z opýtaných neuviedol internetové vyhl'adávače a odkazy z iných lokalít.

Deviata položka zistovala, či mali respondenti nejaké technické problémy pri registrácii.

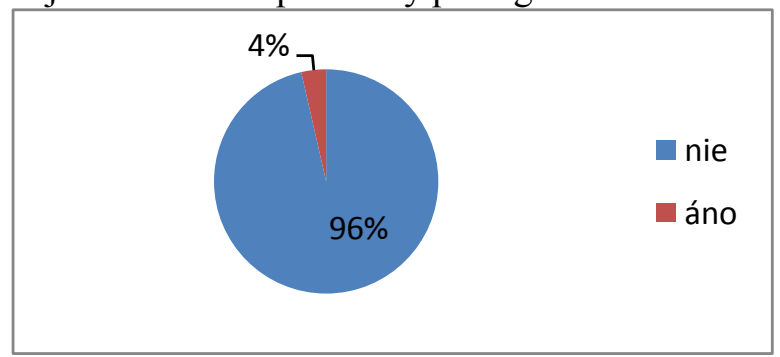

Graf 9 Problémy respondentov s registráciou

$96 \%$ nemalo žiadne problém pri registrácii a $4 \%$ uvádzali problémy s neskoršie doručenými e-mailami, ktoré potvrdzovali registráciu používatel'a. 
Desiata položka kládla otázku: „Inšpirovala Vás práca $\mathrm{s}$ webovou lokalitou EduTech Portal $\mathrm{k}$ vyhl'adávaniu d'alších webových lokalít?“

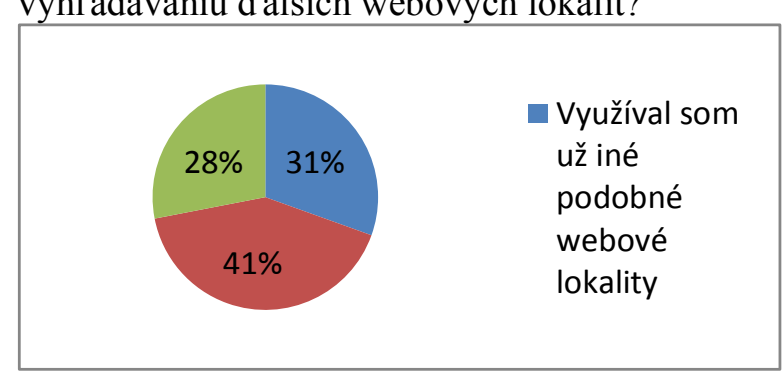

\section{Graf 10 Odpovede na desiatu položku} dotaznika

$41 \%$ respondentov webová lokalita EduTech Portal inšpirovala na vyhl'adávanie podobných lokalít, $31 \%$ využívalo podobné lokality už minulosti a $28 \quad \%$ opýtaných lokalita neinšpirovala.

V poslednej jedenástej položke mohli vyjadrit' respondenti svoje návrhy, pripomienky k webovej lokalite EduTech Portal. Z uvedených odpovedí môžeme uviest', že najviac žiadané boli novšie a d'alšie metodické materiály, ktoré by sa dali využit' priamo vo vyučovacom procese. Rovnako sa vyskytli pripomienky ku grafike webovej lokality.

\section{Diskusia}

$\mathrm{Z}$ výsledkov uvedeného dotazníka môžeme zhrnút' nasledovné závery:

1. Webová lokalita EduTech Portal v rozšírenej verzii pre používatel'ov v Českej republike sa ukázala ako potrebná pre podporu technického vzdelávania na základných školách. Jej rozšírenie umožnila aj obsahová príbuznost' predmetov technika v Slovenskej republike a praktické činnosti $v$ Českej republike. Obsahová náplň bola zabezpečená z oboch strán a ich využitie sa ukázalo ako opodstatnené pre učitel'ov v oboch štátoch.(Serafín, 2012)

2. Dostupnost' webovej lokality, jej správa a prihlasovanie sa javí ako bezproblémové. $\mathrm{Na}$ webovú lokalitu sa postupne registrujú používatelia z oboch krajín. V budúcnosti by bolo potrebné viac spropagovat' jej prevádzku na ostatných školách na všetkých stupňoch.

3. Obsahová náplň lokality je v súčasnosti zabezpečená hlavne formou elektronických pomôcok. Sme toho názoru, že by bolo vhodné skvalitnit' a doplnit' metodické poznámky $\mathrm{k}$ predmetným učebným pomôckam. Záujem práve o túto skupinu pomôcok sa ukazuje ako jeden z najmenších, pričom ide o dôležitú oblast' pre prípravu učitel'a na vyučovanie. $\mathrm{Z}$ dotazníkového šetrenia sa d’alej ukazuje potreba doplnit' obsah materiálov pre spätnú väzbu, hlavne o testy preverujúce poznatky žiakov.

4. Navrhnutá webová lokalita je jedinečná $\mathrm{v}$ tom, že poskytuje bezplatne registráciu a rovnako aj možnost' ju využivat' priamo vo vyučovacom procese. Ide najmä o demonštračné videá, ktoré sú upravené na ich využitie vo vyučovaní. $\mathrm{Na}$ internete prakticky neexistuje lokalita, ktorá by sa priamo špecializovala na technické vzdelávanie na základných školách a zároveň bola garantovaná odborníkmi z didaktiky technických predmetov.

5. Prevádzka webovej lokality bola pozitívne hodnotená a vyzdvihnutá aj $\mathrm{v}$ správe Slovakia VET in Europe - Country report. (2012, s. 41) DEDEFOP. Priebežné výsledky z riešenia projektu boli publikované v odbornom časopise Asociace inovačního podnikání České republiky v príspevku: Diseminace nástrojů metodické podpory učitelů technických předmetů. (Serafín, et all, 2012)

\section{Záver}

Výsledky dotazníkového šetrenia potvrdili opodstatnenost' disseminácie metodickej podpory učitel'ov technických predmetov. Výsledky preukázali záujem o využívanie webovej lokality EduTech Portal ako v Slovenskej a aj v Českej republike. Rovnako aj výsledky projektu zahrnuté $\mathrm{v}$ tomto príspevku naznačili d’alšie možnosti spolupráce pracovísk pripravujúcich budúcich učitel'ov technických predmetov. Potenciál pre spoluprácu vidíme najmä vo výmene študentov učitel'stva technických predmetov a rovnako aj $\mathrm{v}$ komparácii nových prístupov $\mathrm{k}$ technickému vzdelávania $\mathrm{v}$ oboch krajinách.

\section{Literatúra}

[1] EUROPEAN COMISSION, Expert Group on Improving the Education Teachers and Trainers. Changes in Teacher and Trainer Competences. Synthesis Report. [online]. TNTEE, 1998. [cit. 2002-01-11]. Available: http://tntee.umu.se/bulletin_board/the_announce ments/expert_group_a/annex $2 . p d f$

[2]BIRDEN, H - PAGE S.: "Teaching by videoconference: a commentary on best practice for rural education in health professions." In Rural and Remoty Health. Online (2005). Available: http://rrh.deakin.edu.au

[3] KROPÁČ , Jiř́., Zbyněk KUBÍČEK, Miroslav CHRÁSKA, a Martin HAVELKA. Didaktika 
technických predmětũ: vybrané kapitoly. Olomouc, Univerzita Palackého, 2004. 223 s. ISBN 80-244-0848-1.

[4] Projekt APVV č. SK-CZ-0042-11 Disseminácia nástrojov metodickej podpory pre ucitel'ov technických predmetov. 2011 Zodpovedný riešitel' Gabriel Bánesz

[5] VANTUCH, J. - JELINKOVA, D.: Slovakia VET in Europe - Country Report. REFERNET, CEDEFOP Slovakia, 2012. (online). [cit. 201406-13]. Dostupné z: http://www.cedefop.europa.eu/EN/Informationservices/vet-in-europe-country-reports.aspx [6] SERAFÍN, Č. - PROCHÁZKOVÁ, I.: Školni vzdélávaci program (ŠVP) jako inspirační zdroj inovace výuky predmětu všeobecného technického charakteru. In. Technické vzdelávanie ako súčast' všeobecného vzdelávania. Banská Bystrica: UMB, 2009. ISBN 978-80-8083-878-2 s. 440 - 444

[7] SERAFÍN, Č. - DOSTÁL, J. - HAVELKA, M. - KUBRICKÝ, J.: Nástroj metodické podpory učitelù obecne technických předmetù. In. Trendy ve vdělávání 2012. s. 269 - 274 ISSN 1805-8949 [8] SERAFÍN, Č. - DOSTÁL, J. - HAVELKA, M. - KUBRICKÝ, J. - BÁNESZ, G. LUKÁČOVÁ, D. - HAŠKOVÁ, A. - SITÁS̆, J.: Diseminace nástrojů metodické podpory učitelu technických predmetũ: česko slovenská spolupráce, projekt 7AMB12SK106, 2012. In: Inovační podnikání \& transfer technologií: odborný časopis Asociace inovačního podnikání České republiky: pŕíloha ip\&tt 4/2012 - transfer technologií. - ISSN 1210-4612, Roč. 2012, č. 4 (2012), s. 6-7.

doc. PaedDr. Gabriel Bánesz, PhD.

Katedra techniky a informačných technológií

Pedagogická fakulta UKF v Nitre

Dražovská 4

94974 Nitra, SR

Tel: +421 376408342

E-mail: gbanesz@ukf.sk

Www pracoviska: www.ktit.pf.ukf.sk

doc. PaedDr. Danka Lukáčová, PhD.

Katedra techniky a informačných technológií

Pedagogická fakulta UKF v Nitre

Dražovská 4

94974 Nitra, SR

Tel: +421 376408342

E-mail: dlukacova@ukf.sk

Www pracoviska: www.ktit.pf.ukf.sk 